\title{
ORGAN TRANSPLANTATION, ETHICS, AND ROLE OF MEDICAL COMMUNITY AND MEDIA IN PAKISTAN
}

\author{
Maryam Sultan Khan
}

Public Health Associate, Department of Health, Government of Sindh

Correspondence: Maryam Sultan Khan, Email: sk.maryum@hotmail.com

\section{Introduction}

Organ trafficking is one the most heinous crime committed worldwide, which includes forced labor, slavery and removal of various human organs According to the United nations office of drugs and crime, human trafficking is believed to be the most profitable business (1). Over the years shortage of organs transplant waiting list has somehow made well off foreigners to travel to poor countries for transplant, which is commonly referred as transplant tourism. Moreover that approximately 10 per cent of the 63,000 kidney transplantations across the globe involves transaction between non-related donors of different nationalities (2). Organ transplantation is removal of tissues from human from either a living or dead person for the transplantation as treatment In simple words transplant tourism can be explained as an individual suffering from life-threatening and irrevocable organ failure travels to other country for organ transplantation (3). United States trafficking in person (TIP) has reported that Pakistan has become haven for transit and destination country in terms of forced labor and sexual mistreatment (4). Pakistan over the years has become hub for illegal renal transplants before to commence the renal transplantation rule. In addition to that World health organization report has stated that top five culprit countries for organ-trafficking includes China, Colombia, Egypt and Pakistan, whereas kidneys are the most common organ which has been trafficked as it can be easily removed and preserved (5). Previously, in Pakistan approximately 6,500 kidneys are sold every year, moreover there are reports that intestines, pancreas and lungs are sold in black market of organs within the country. Kidney transplantation in Pakistan started between living donors in hospitals in 1980. However organ trafficking in Pakistan began in early 90's in which majority unrelated transplant started on wealthy foreigners who wanted to buy cheap organs from black market. Also the private clinics in the country began to take advantage from this illegal organ business since there was no explicit law prohibiting organ trafficking and illegal transplantation. There is no precise data regarding transplant tourism as to how many foreigners travelled to Pakistan specifically for organ transplantation (6).

\section{Legal issues}

The Government of Pakistan Supreme Court ruling formulated Transplantation of Human Organs and Tissues bill 2007. The bill explicitly proposes various procedures including restraints on organ donation only to close blood relatives above 18 years of age. This bill also strictly recommends 10 year jail sentence for any individual involved in illegal organ trade business. Pakistan has still no law regarding transplantation of organs from dead persons. Hence meticulous effort is expected from Government and its law enforcement apparatus along with public health sectors to put an end to this savage organ trade business (5).

\section{Islamic perspective on organ donation}

In the light of various Islamic laws on organ donation, it can be concluded that treatment of any kind of ailment is permissible and obligatory. However mutilation of organs and violations of dead corpse is severely prohibited. Moreover it is permissible for any person to donate organ from his body to save life of any individual in need of any organ. But according to Islamic laws organs should not be sold and thus be donated to people in need according to a proper procedure. Pakistan is a country with low literacy rate therefore increases awareness regarding bioethical issues to articulate considered opinion in implementing laws associated to organ transplantation. Clerics and religious scholars should be taken in loop for their judgment while formulating laws and rules about bioethical issues (6).

\section{Ethical issues}

Ethical theories narrate universal moral duties and many people consider it to be either religious or ethical code for having empathy and compassion to fellow human being and treating them as one wishes to be treated by others (7). Decision making for organ transplantation involves bioethical principles like autonomy, beneficence and justice. Therefore health security of each individual should be the principal goal of healthcare policies and 
interventions. It is imperative to assess risk-benefit ratio with focus on fairness and equality of human beings. Also integrity of donor and recipients must be respected, moreover need for informed approval without intimidation must also be done keeping in view accurate and plausible information (8).

Principle of sovereignty is at the heart of western society and is in tandem with independent individual who has all the right to reason, comprehend and thus decide and make rational choices for his or her own benefit. It implies that health practitioners should respect wishes of patient and thus keep in view the feelings and choice for their medical decision (9).

\section{Advocacy by the medical community}

It is prime responsibility of moral entrepreneurs, groups and individual in civil society to eliminate illegal organ trade in Pakistan. Local physicians should act as moral entrepreneurs and raise Government awareness towards exploitation of poor people for selling organs illegitimately. Organ removal can have a detrimental consequence on donor's health condition and at times endanger his life during removal process. However in Pakistan Sindh Institute of Urology and Transplantation (SIUT) lead the campaign against illegal organ transplantation, formulating a precise legislation against increasing inflow of transplant tourists in Pakistan (10).

\section{Role of media}

Media is the most powerful medium and tool against any crime in this modern day and age. It also forces and motivates Government to curb any illegal trade exploiting poor sections of society. By providing wide publicity media can bring Government and people attention to this glaring issue of illegal organ trade in Pakistan. Once the law-breaking is uncovered and the criminals are identi?ed, governments come under pressure to acknowledge and address the problem (11).

\section{Mass campaign against organ trafficking}

Local and international humanitarian organizations should initiate a mass campaign reaching out to the far flung rural areas of Pakistan. Aim of this campaign should be to sensitize the poor and deprived sections of the society so that they cannot be exploited by organ trade mafias. This campaign will require social mobilizers to inform and educate illiterate people of rural areas (12).

\section{Conclusion}

Main underlying factors of organ trafficking in Pakistan are poverty, unemployment, illiteracy, lack of health care infrastructures, social services and poor implementation of THOTO (Transplantation of Human Organs and Tissues) bill which was formulated in 2007 by Government of Pakistan. In order to stop this illegal organ trade business responsible Government officials needs to step up and efficiently implement renal transplantation law efficiently. Moreover it should also assist victims of organ trafficking with better health care post operation. Prosecute various actors involved in illegal organ trade business.

\section{References}

1 Shelley, L. I. Human trafficking: A global perspective. Cambridge,UK: 2010; Cambridge University Press.

2 Garwood, P. Dilemma over live-donor transplantation. Bulletin of the World

$\begin{array}{ll}\text { a. Health Organization 2007; 85(1): 5-6. } \\ 3 & \text { Budiani-Saberi, D. A., Delmonico, F. L.'Ethics }\end{array}$ Corner: Organ Trafficking and Transplant Tourism: A Commentary on the Global Realities', American Journal of Transplantation, 2008; 8(05): 925-29.

4 Naqvi, S. A. A., Ali, B., Mazhar, F., Zafar, M. N., \& Rizvi, S. A. H. A socioeconomic survey of kidney vendors in Pakistan, Transplant international official journal of the European Society for Organ Transplantation, 2007; 20(11):934-39.

5 IRIN. Pakistan: Government mulls new law on Illegal kidney sale 2007.

6 Kazim, S.F Organ donation law in Pakistan: An overview of the current situation', Journal of Pakistan Medical Association 2008;58(2):99100.

7 Ilyas Muhammad, Alam Mukhtar, Ahmad Habib. The Islamic perspective of organ donation in Pakistan', Saudi J Kidney Dis Transpl 2010; 20(1):154-156.

8 Holland, S. Public Health Ethics, Cambridge, Polity 2007.

$9 \quad$ Taher LS. Moral and ethical issues in liver and kidney transplantation, Saudi J kidney Dis Transpl, 2010; 16: 375-82.

10 Beauchamp and Childress. Principles of biomedical ethics 6th edition, Newyork: oxford university press 2008.

11 Harel I, Kogut T, Pinchas M, and Slovic P. Effect of media presentations on willingness to commit to organ donation, Proceeding of National Academy of Sciences of United States of America 2017; 114(20): 5159-64.

12 Alexander M. Capron \& Francis L. Delmonico. Preventing Trafficking in Organs for Transplantation: An Important Facet of the Fight Against Human Trafficking, Journal of Human Trafficking 2015; 1(1):56-64. 